\title{
Correction to: Isolation of xylans from bleached Eucalyptus kraft pulp by antisolvents precipitation
}

\author{
Ana Isabel Marques (1D - Maria de Lurdes Serrano - Ana Maria Brites Alves • \\ António P. Mendes de Sousa
}

Published online: 9 February 2019

(C) Springer Nature B.V. 2019

\section{Correction to: Cellulose https://doi.org/10.1007/s10570-018-1941-x}

Unfortunately, the word "FTIR" has been mistakenly included in the Acknowledgments, which needs to be removed.

The correct Acknowledgments is provided in this correction.

Acknowledgments The authors wish to thank Prof. Ana Paula Dias (IST) for her help in thermogravimetric analysis, RAIZ for the collaboration in HPAEC analysis and pentosan determination and Prof. Dmitry Evtuguin and Dr. Ana Reis from Aveiro University for the collaboration in GPC analysis.

Publisher's Note Springer Nature remains neutral with regard to jurisdictional claims in published maps and institutional affiliations.

The original article can be found online at https://

doi.org/10.1007/s10570-018-1941-x.

A. I. Marques $(\bowtie) \cdot$ M. L. Serrano CERENA, Chemical Engineering Department, Instituto

Superior Técnico, Avenida Rovisco Pais, 1,

1049-001 Lisbon, Portugal

e-mail: anadafonsecamarques@gmail.com

A. I. Marques - A. M. B. Alves

CeFEMA, Chemical Engineering Department, Instituto Superior Técnico, Avenida Rovisco Pais, 1,

1049-001 Lisbon, Portugal

A. I. Marques - A. P. M. de Sousa

RAIZ, Instituto de Investigação da Floresta e Papel,

Quinta de S. Francisco, Apartado 15, 3801-501 Eixo,

Portugal 